\title{
Psykoser hos barn og ungdom
}

\author{
Psykoser forbindes vanligvis med voksne, men forekommer også hos barn og unge. Det er viktig å komme \\ tidlig til med behandling, og studier har vist at varighet av ubehandlet psykose har betydning for prognose, \\ selvmordsrisiko og livskvalitet. Likevel er varigheten av ubehandlet psykose lengre hos unge enn hos voksne.
}

Publisert først på nett 28.3. 2012

Psykose hos unge er vanligvis preget av udifferensierte symptomer, høy grad av komorbiditet og snikende debut. Tilstanden kan være vanskelig å oppdage, og studier viser at varigheten av ubehandlet psykose (VUP) er lengre for ungdom enn for voksne (1-3).

Behovet for kompetanseheving på tvers av ulike instanser i hjelpeapparatet er stort. Det er spesielt viktig at allmennpraktikere besitter denne kompetansen, siden de ofte er den første instansen de unge henvender seg til. Med utgangspunkt i Veileder for utredning av barn og ungdom med psykoser gir vi her en kort oversikt over karakteristika ved psykoser og psykoserisiko hos unge og viktige behandlingselementer (1).

\section{Forekomst og etiologi}

Psykosespekteret favner både schizofreni, affektive psykoser, rusutløste psykoser og organiske psykoser. Diagnosekriteriene for unge er de samme som for voksne, men symptomer kan fremstå som forskjellige på ulike utviklingsnivåer. Schizofreni anser vi som den alvorligste av psykosespekterlidelsene. Hos barn opp til 12 år er schizofreni lavfrekvent (1/10 000), med en suksessivt høyere forekomst fra 13 år og oppover (1). I litteraturen anslår man en prevalens av schizofreni på $0,2-0,4 \%$ hos unge mellom 13 og 18 år, men det er ingen gode studier på dette (1). Registerdata fra Storbritannia viser en prevalens av psykotiske lidelser på $0,4 \%$ i aldersgruppen 5-18 år, og at 24,5\% av innleggelsene i sengepost for ungdom skyldtes schizofreni (4). En australsk studie av psykosepasienter med en første episode viste at $20 \%$ debuterte med en psykosespekterlidelse før fylte 18 år, mens $50 \%$ av de som debuterte med schizofreni, gjorde dette før fylte 18 år (2).

Psykoseutvikling blir ofte forklart ut fra en stress- og sårbarhetsmodell som illustrerer hvordan sårbarhetsfaktorer $\mathrm{i}$ individet og miljømessige variabler i samspill kan utløse en psykose (5). Etiologien er uklar og sannsynligvis multifaktoriell, men mye tyder på at biologiske variabler spiller en større rolle ved tidlig debut enn ved senere debut (6). De vanligste risikofaktorene for psykoseutvikling er, foruten genetisk sårbarhet og funksjonsfall, perseptuelle endringer, sosial tilbaketrekning, nedsatt stemningsleie/depresjon, søvnvansker og generelle/diffuse symptomer (7).

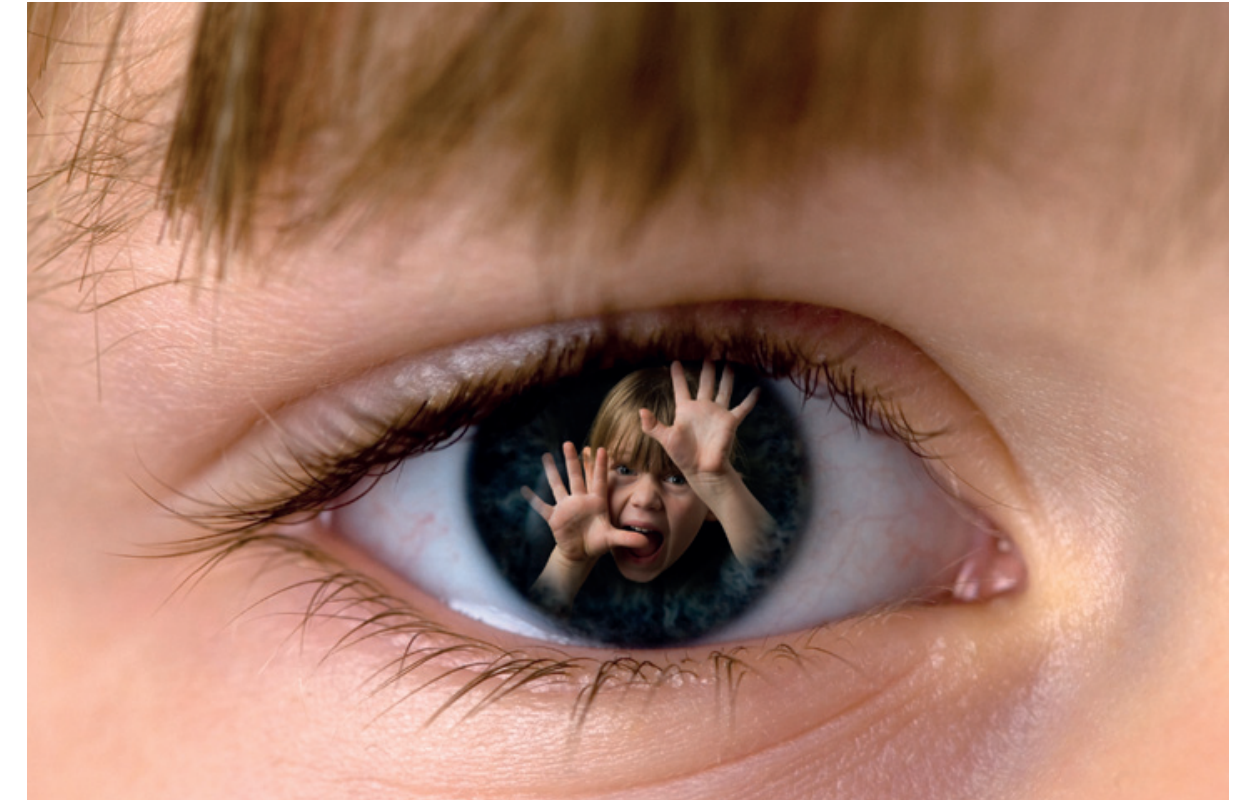

Illustrasjonsfoto Istockphoto

\section{Utredning}

Unge forteller ikke automatisk om psykoseliknende opplevelser. Ved mistanke om psykose bør man stille direkte spørsmål om psykotiske symptomer, gjerne med utgangspunkt $i$ et strukturert intervju. Barnets indre verden må utforskes, og barnet må få hjelp til å sette ord på opplevelsene. Symptomer varierer gjerne $i$ intensitet og innhold, avhengig av opplevd stressnivå og andre faktorer. Det at symptomer ikke er til stede kontinuerlig betyr ikke at man kan utelukke en psykoselidelse (1). En utredning bør alltid, i tillegg til et grundig diagnostisk intervju, innbefatte både anamnese, somatisk status, evnevurdering og kartlegging av mestringsområder. Kjennskap til utviklingspsykologi er avgjørende, og utredningen bør foretas av en spesialist i barnepsykiatri eller barnepsykologi.

\section{Symptomer}

Vanlige symptomer, som skal være til stede en vesentlig del av tiden på minst én måned, er: positive symptomer (hallusinasjoner, vrangforestillinger, tankeforstyrrelser) og/eller negative symptomer (apati, taleforstyrrelser, avflatede emosjoner eller tilbaketrekning) (8). En klinisk vurdering innebærer vurdering av symptomenes alvorlighetsgrad, intensitet, hyppighet, avvik og grad av ubehag/plage. Dette må man vurdere opp mot alder, utviklingsnivå og miljømessige og kulturelle forhold (1). Symptomer omhandler ofte endring i tenkning og persepsjon og er ikke umiddelbart observerbare. Ofte ser man en periode på måneder eller år med psykoseliknende symptomer forut for psykosedebut $(1,7)$.

I tillegg til psykotiske symptomer må man også se etter funksjonsfall, angst, konsentrasjonsvansker, søvnvansker, depresjon, reguleringsvansker, uvirkelighetsfølelse, forvirring, tvang/rigiditet, sosiale og emosjonelle vansker og generell atferdsendring (8). Generelt sett er det slik at psykotiske symptomer hos barn arter seg noe annerledes enn hos voksne, og at det er en gradvis overgang fra den barnlige formen til den vi kjenner fra voksne.

\section{Hallusinasjoner og vrangforestillinger}

Hos barn er innholdet i hallusinasjoner og vrangforestillinger gjerne enkelt og knyttet opp mot konkrete forhold (leker, dyr, foreldre og venner), og hallusinasjoner fra flere sansemodaliteter er mer vanlig enn hos voksne (9). Enkeltstående hallusinasjoner gir ikke alene grunn til bekymring, men opptrer de sammen med symptomene nevnt $i$ avsnittet over, bør man henvise til en psykoseutredning. Det samme gjelder 
om barnet blir urolig av hallusinasjonene, styrt av dem eller hvis innholdet oppleves som bisart (1).

\section{Tankeforstyrrelser,}

desorganisering og funksjonsfall

Løse assosiasjoner og ulogisk tenkning forekommer ofte ved psykose hos barn. Dette kan komme til uttrykk både gjennom springende og assosiativ tale eller lek som virker uorganisert (uten mål og mening eller uten sammenheng) og knyttet opp mot konkrete forhold (leker, dyr, foreldre og venner). Funksjonsfall eller tap av ferdigheter med snikende utvikling er vanlig. For å avdekke dette må man i tillegg til å vurdere fungering på ulike felter vurdere hvor mye barnet må streve for å få til det samme som før. Eksempelvis kan et barn eller en ungdom med tidlig fase av psykose prestere det samme som tidligere på skolen, men trenge mye lengre tid på oppgaven og bli uforholdsmessig sliten av den.

\section{Differensialdiagnoser og komorbiditet}

Differensialdiagnostisering er utfordrende hos unge. Symptombildet er ofte udifferensiert og har utviklet seg så gradvis at pasienten opplever symptomene som en selvfølgelig del av seg selv. Vanlige differensialdiagnoser er, i tillegg til affektive psykoser, depresjon, traumer/dissosiasjon, gjennomgripende utviklingsforstyrrelser, tvangslidelse (OCD) og rusutløste psykoser (1). Komorbide tilstander, spesielt $\mathrm{AD} / \mathrm{HD}$, opposisjonell atferdsforstyrrelse og rusmisbruk, er også vanlige (10).

Ulike organiske tilstander som hjernetumor og sykdommer i sentralnervesystemet, bivirkninger av ulike legemidler, sansedeprivasjon og epilepsi kan også medføre psykose eller psykoseliknende symptomer (11).

$\mathrm{Vi}$ vet $\mathrm{i}$ dag at ulike former for rusmisbruk kan utløse kortvarige psykoser, og at cannabis øker risikoen for konvertering til psykose i høyrisikogrupper (8). Bruk av rusmidler må derfor utforskes nøye - selv når ungdommen avviser slik bruk. Det er også verdt å merke seg at barndomstraumer, spesielt seksuelt misbruk og fysisk mishandling, øker risikoen for psykose (12).

\section{Behandling}

I Veileder for utredning av barn og ungdom med psykoser refererer man til flere artikler hvor man anbefaler et integrert behandlingsprogram, der både medikamenter, samtaleterapi, psykoedukasjon, familie- og nettverksarbeid og sosial ferdighetstrening inngår (1). (Revidert veileder forventes å foreligge i mai 2012.) Oppfølgingen bør vare i mange år. Grunnet stor kompleksitet i sykdomsbildet og relativt lav frekvens av tilstanden, må behandlingen være forankret i spesialisthelsetjenesten. Innleggelser er til tider nødvendig, men man må være klar over at det er en belastning for barn å være borte fra hjemmet og sin naturlige utviklingsarena. Virkningen av medisiner er også mer kompleks enn hos voksne, og faren for bivirkninger er større (13). Medisiner bør derfor forskrives av barnepsykiater eller psykiater. Ved risikotilstander prøver man som regel først psykososiale tiltak for å se om dette stopper symptomutviklingen.

\section{Konklusjon}

Mye tyder på at psykoser hos barn og ungdom er mer vanlig enn hva mange klinikere er seg bevisst, og at mange unge går lengre tid med ubehandlet psykose enn hva voksne gjør (1-3). Hvis en 15-åring har hatt en uoppdaget psykose i $21 / 2$ år, tilsvarer dette $1 / 6$ av vedkommendes liv. Hos barn og ungdom vil en sykdomsfase påvirke selve utviklingsprosessen og er på den måten enda mer gjennomgripende enn hos voksne.

Helsetjenesten bør vie denne gruppen større oppmerksomhet, både for å øke mulighetene for å forebygge lidelse og fordi det har vist seg ha en samfunnsøkonomisk gevinst (14).

\section{Kjersti Karlsen}

uxkkje@ous-hf.no

TIPS Sør-Øst - Regionalt kompetansesenter for tidlig intervensjon ved psykose Klinikk psykisk helse og avhengighet Oslo universitetssykehus, Ullevål

Kjersti Karlsen (f. 1965) er psykologspesialist med klinisk fordyping barn og ungdom. Hun er ansatt ved TIPS Sør-Øst - Regionalt kompetansesenter for tidlig intervensjon ved psykoser og har der ansvar for å bygge opp psykosekompetansen i BUP i Helseregion Sør-Øst. Forfatteren har fylt ut ICMJE-skjemaet og oppgir ingen interessekonflikter.
Litteratur

1. Karlsen K. Veileder for utredning av barn og ungdom med psykoser i Helse Sør-Øst. www.oslo-universitetssykehus.no/omoss/ avdelinger/tips-sor-ost/Sider/ utredningsveiledere.aspx (20.3.2012)

2. Schimmelmann BG, Huber CG, Lambert M et al. Impact of duration of untreated psychosis on pretreatment, baseline, and outcome characteristics in an epidemiological first-episode psychosis cohort. J Psychiatr Res 2008; 42: 982-90.

3. Langeveld J. Psykose med debut i ungdomsalderen - funn fra TIPS-studien. Best Practice 2010; 4: $12-5$.

4. Psychosis and schizophrenia in children and young people: final scope 2011. London: National Institute for Health and Clinical Excellence, 2011. www.nice.org.uk. (20.3.2012).

5. Pruessner M, Iyer SN, Faridi K et al. Stress and protective factors in individuals at ultra-high risk for psychosis, first episode psychosis and healthy controls. Schizophr Res 2011; 129: 29-35.

6. Rapoport JL, Gogtay N. Childhood onset schizophrenia: support for a progressive neurodevelopmental disorder. Int J Dev Neurosci 2011; 29: $251-8$.

7. Yung AR, Klosterkötter J, Cornblatt B et al. At-risk mental state and prediction. in Jackson PD, Mc Gorry HJ. The recognition and management of early psychosis. A preventive approach. Cambridge: Cambridge University Press, 2009.

8. ICD-10. Psykiske lidelser og atferdsforstyrrelser Kliniske beskrivelser og diagnostiske retningslinjer. Oslo: Universitetsforlaget, 1999.

9. David CN, Greenstein D, Clasen L et al. Childhood onset schizophrenia: high rate of visual hallucinations. J Am Acad Child Adolesc Psychiatry 2011; 50: 681-6. e3.

10. Reimherr JP. McClellan JM. Diagnostic challenges in children and adolescents with psychotic disorders. J Clin Psychiatry 2004; 65 (Suppl 6): 5-11.

11. Cepeda C. Psychotic symptoms in children and adolescents. Assessment, differential diagnosis and treatment. New York, NY: Routledge Taylor \& Francis Group, 2007.

12. Klæth JR, Hagen R. Sammenhengen mellom barndomstraumer og senere utvikling av psykotiske lidelser. Tidsskr Nor Psykologforen 2009; 46: $1049-55$

13. Vitiello B, Correll C, van Zwieten-Boot B et al. Antipsychotics in children and adolescents: increasing use, evidence for efficacy and safety concerns. Eur Neuropsychopharmacol 2009; 19 629-35.

14. McCrone P, Craig TKJ, Power P et al. Cost-effectiveness of an early intervention service for people with psychosis. Br J Psychiatry 2010; 196: 377-82.

Mottatt 11.10. 2011, første revisjon innsendt 13.2 . 2012, godkjent 1.3. 2012. Medisinsk redaktør Are Brean. 